Portland State University

PDXScholar

Educational Leadership and Policy Faculty

Publications and Presentations

$7-2006$

\title{
The pedagogy of oppression: A brief look at the 'No Child Left Behind'
}

\author{
Ramin Farahmandpur \\ Portland State University, farahmandpur@comcast.net \\ Peter McLaren \\ University of California - Los Angeles
}

Follow this and additional works at: https://pdxscholar.library.pdx.edu/elp_fac

Part of the Educational Assessment, Evaluation, and Research Commons

Let us know how access to this document benefits you.

\section{Citation Details}

McLaren, P. and Farahmandpur, R. (2006). The Pedagogy of Oppression. Monthly Review: An Independent Socialist Magazine, 58(3), 94.

This Article is brought to you for free and open access. It has been accepted for inclusion in Educational Leadership and Policy Faculty Publications and Presentations by an authorized administrator of PDXScholar.

Please contact us if we can make this document more accessible: pdxscholar@pdx.edu. 


\section{The Pedagogy of Oppression A Brief Look at 'No Child Left Behind'}

\section{PETER MCLAREN \& RAMIN FARAHMANDPUR}

The origins of the current standards-based movement in public education can be traced back to the early twentieth century when curriculum theorists like Ellwood Cubberley and others attempted to align school curricula to the needs and demands of the U.S. economy by developing a scientific approach to designing and planning them. ${ }^{1}$ From the 1950s to the 1970s, with the Cold War in full swing, the "back to basics" movement gained momentum in teacher education programs and graduate schools of education. Supporters of the movement were determined to ensure that school curricula reflected not only the ideologies and political views of the dominant social classes in the United States, but that they also prepared students for employment in the growing military industrial complex to defend the country against the so-called communist threat.

A report published in 1983, A Nation at Risk, was another significant milestone in the history of the education reform movement. ${ }^{2}$ The report vilified schools for the relatively weak economic performance of the United States compared to its Asian and European rivals.

The driving forces behind the recent educational policies of the No Child Left Behind Act passed in 2001 are neoliberal social and economic policies that favor outsourcing and downsizing methods of production in the name of flexibility and efficiency. Under the neoliberal economic model, schools must perform similarly to corporate entities. Just as the Dow Jones stock indices measure the performance of companies and represent the pulse of Wall Street, so too the Adequate Yearly Progress Report (AYP) measures and ranks the performance of public

Peter McLaren (mclaren@gseis.ucla.edu) teaches in the Graduate School of Education and Information Studies of the University of California, Los Angeles. His most recent book is Rage and Hope: Interviews with Peter McLaren on War, Imperialism, and Critical Pedagogy (Peter Lang Publishing, 2006).

Ramin Farahmandpur (farahmandpur@comcast.net) teaches in the department of Educational Policy, Foundations and Administrative Studies in the Graduate School of Education at Portland State University and, with Peter McLaren, is coauthor of Teaching Against Global Capitalism and the New Imperialism: A Critical Pedagogy (Rowman \& Littlefield, 2005). 
schools. One of the most pernicious results of the No Child Left Behind Act is that states can now indefinitely close or restructure "underperforming schools," those that fail to meet the requirements established by the AYP.

An emphasis on testing, resulting in a teaching-to-the-test mania, strict accountability schemes, prepackaged and scripted teaching for students of color, and a frenetic push towards more standardized testing (what Jonathan Kozol refers to as "desperation strategies that have come out of the acceptance of inequality") has been abundantly present since the mid-1990s. But what has this trend produced? $?^{3}$ As Kozol points out, since the early 1990s, the achievement gap between black and white children has substantially widened at about the same time as we began to witness the growing resegregation of the schools (when the courts began to disregard the mandates of the Brown decision). ${ }^{4}$ This has led to what Kozol calls "apartheid schooling." Kozol reports that in 48 percent of high schools in the country's largest districts (those that have the highest concentrations of black and Latina/o students) less than half of the entering ninth-graders graduate in four years. Between 1993 and 2002, there has been a 75 percent increase in the number of high schools graduating less than half of their ninth grade high school class in four years. In the 94 percent of districts in New York State where the majority of the students are white, nearly 80 percent of students graduate from high school in four years. In the 6 percent of districts where black and Latina/o students make up the majority, the percentage is considerably less-approximately 40 percent. There are 120 high schools in New York (enrolling nearly 200,000 minority students) where, Kozol notes, less than 60 percent of entering ninth-graders make it to the twelfth grade.

With the neoliberal agenda in full swing, the No Child Left Behind Act has shifted the discourse of progressive educational policy from "equality" to "adequacy." The language of "higher standards" and "higher expectations" has replaced the low-intensity social justice agenda of the center/left educators. Kozol debunks the conceptual frameworks used to explain the causes of underachievement among students of color. As part of the daily rituals and practices designed to raise student morale, schools now employ what Kozol refers to as "auto-hypnotic slogans." In schools that are identified as "under-performing," students of color are encouraged to memorize phrases such as "I can," "I am smart," and "I am confident" to boost their self-confidence and to improve their academic performance. 
Kozol suggests that researchers need to do more than study the "psychological effects" of poverty and oppression to find solutions to the social problems children face. He argues that as a society we need to invest more in social services such as health care and employment opportunities to improve the lives of children in urban communities.

Today urban schools are adroitly organized around the same principles as factory production lines. According to Kozol, "raising test scores," "social promotion," "outcome-based objectives," "time management," "success for all," "authentic writing," "accountable talk," "active listening," and "zero noise" constitute part of the dominant discourse in public schools. ${ }^{6}$ Most urban public schools have adopted business and market "work related themes" and managerial concepts that have become part of the vocabulary used in classroom lessons and instruction. In the "market-driven classrooms," students "negotiate," "sign contracts," and take "ownership" of their own learning. In many classrooms, students can volunteer as the "pencil manager," "soap manager," "door manager," "line manager," "time manager," and "coat room manager." In some fourth-grade classrooms, teachers record student assignments and homework using "earning charts." In these schools, teachers are referred to as "classroom managers," principals are identified as "building managers," and students are viewed as "learning managers." It is commonplace to view schoolchildren as "assets," "investment," "productive units," or "team players." Schools identify the skills and knowledge that students need to learn and acquire as "commodities" and the "products" to be consumed in the "educational marketplace." Under the current climate of the No Child Left Behind school reform movement, teachers are regarded as "efficiency technicians" and encouraged to use "strict Skinnerian control" methods and techniques to manage and teach students in their classroom. Kozol writes that in the market-driven model of public education, teachers are viewed as "floor managers" in public schools, "whose job it is to pump some 'added-value' into undervalued children."

To the disdain of progressive educators, the test craze is now a growing trend in most large metropolitan public school districts. In some districts, standardized testing begins in kindergarten. Some public schools have been forced to cut back or entirely remove art and music classes from their school curriculum. Other schools have reduced or altogether eliminated recess and/or nap time. Most public schools now have a testing coordinator. During homeroom, for example, school administrators encourage teachers to teach students test-taking skills and 
strategies. The Los Angeles Unified School District has developed its own quarterly assessment tests in math, science, social studies, and English. The district tests students every two months. We are told that the purpose of these district assessment tests is to prepare students for the statewide standardized tests in late spring. At teacher and staff development meetings, most of the time is spent on sharing and discussing effective strategies and methods to prepare students for quarterly assessment tests and to review state and districts standards. Teachers are also encouraged to attend workshops and conferences to learn more on how to align their teaching practices to the state standards.

As the standardized curriculum and standardized testing widen the achievement gap between poor and wealthy school districts, workingclass students and students of color continue to be tracked into vocational programs and classes that teach life-skills or offer basic training that prepares them for jobs in the retail and service industry. ${ }^{8}$ Even more disturbing perhaps is the placement of high school female students in sewing and cosmetology classes. As we know by now, these classes do little for students who must compete with advanced placement and college-tracked students. It is painfully ironic that just as we are witnessing the factory model of schooling returning with a vengeance, the factories of yesteryear in which working-class students traditionally sought employment after graduation are moving out of the country, escaping the unions and depriving workers of medical benefits.

Provisions within the No Child Left Behind legislation have removed any obstacles to the recruitment efforts of the military to target high school students, in particular vulnerable students of color in urban public schools. The military has engaged in dirty recruitment campaigns and tactics to lure high school students to enlist in the army, including visiting classrooms and making weekly phone calls to potential high schools students to pressure them to join the army. Other strategies include driving Humvees to schools blasting hip-hop music and distributing free T-shirts and "Yo Soy El Army" stickers. What is unsettling is that the army spends $\$ 13,000$ in advertisements for each potential recruit, which is about the same amount of money to educate one child for one year in the New York public school system. In response, many students, teachers, and principals have organized local and national coalitions such as the Coalition Against Militarism in our Schools (CAMS) to resist military recruitment efforts in their community schools. Recently, the School Leadership Council at Roosevelt High School, located in the working-class Latina/o community of East Los Angeles-recognized as 
the number one "marine-recruited school in the nation"-passed a resolution to restrict military recruitment efforts at their high school. ${ }^{9}$

And if all this isn't bad enough, the military defense budget continues to swell at the expense of funding public education. In the 2002-2003 annual budget, state tax revenues sharply fell by $\$ 22$ billion compared to the previous year. The Bush administration's decision to abolish the estate tax will cause an additional $\$ 10$ billion loss in revenues. The impact of the Bush administration's social and economic policies has been devastating for public schooling, forcing many school districts to reduce school programs and services. As David Goodman notes:

Schools around the country are reeling from the cuts. In California, where 3,800 teachers and 9,000 other school employees received pink slips last year, districts have cut textbook purchases, summer school, bus routes, maintenance, athletics, student newspapers, and electives. Half of the school districts in Kansas have cut staff; several districts have gone to a four-day week; and 50 schools in Kansas now charge students to participate in some extracurricular activities. In Michigan, funding for gifted and talented students is down 95 percent; Buffalo, New York, has been forced to close eight schools and eliminate 600 teaching jobs over the past years. ${ }^{10}$

Faced with the shortage of revenues to support their existing educational programs, many school districts have been forced to develop partnerships with corporations eager to step into the lucrative education market. Consider McDonald's recent adoption of a new strategy to promote its products in the highly profitable market dominated by children. This comes after the highly publicized libel suit now famously referred to as the McLibel Case and the recent film, Super Size Me, which raised ethical and moral questions regarding McDonald's food processing and preparing practices that many believe have significantly contributed to increasing obesity and other health risks among children. Nancy Hellmich reports that in an effort to restore its much-tarnished public image as the family-friendly fast-food chain, and to further protect its market share, McDonald's has decided to capitalize on physical education programs in public schools. ${ }^{11}$ Over seven million students in 31,000 public schools have agreed to participate in McDonald's "Passport to Play" program. The program consists of a number of multicultural physical education activities including "boomerang golf" from Australia, "Mr. Daruma Fell Down" from Japan, and Holland's "Korfball." Students who complete each of these activities receive a 
stamp in their passport issued by McDonald's. According to Bill Lama, McDonald's chief marketing officer, the objective of the Passport to Play program is to educate students on the "importance of eating right" and "staying active." Such a strategically calculated move allows McDonald's not only to recover from much of the negative publicity it has received in the past few years, but it also helps the food chain to secure a greater presence and visibility in public schools.

There have been a large number of movements and protests that have developed over the past twenty years in opposition to neoliberalism and the attendant attack on public education. Among these have been the antiglobalization movement, the immigration rights movement, the mass demonstrations in France in protest of neoliberal labor legislation, the factory takeover movement in Argentina, the victories of Chávez in Venezuela and Morales in Bolivia, and many others. These movements, in turn, have sparked the growth of coalitions comprised of social movements, progressive organizations, labor unions, community activists, and ordinary citizens who are collectively engaged in various forms of struggles and resistance against global capitalism and U.S. imperialism.

While exemplary in their intent and actions, most of these movements have treated the symptoms of neoliberalism rather than the disease. What is missing is the understanding of the nature of capitalism, an understanding only possible through the use of a Marxian analysis. A crucial part of every movement needs to be, therefore, a critical pedagogy, one that pushes the participants in every movement, including, of course, the radical education movement, to think and act critically.

\section{Notes}

1. Christine Sleeter, Un-standardizing Curriculum: Multicultural Teaching in the Standards-based Classroom (New York: Teachers College Press, 2005).

2. Ibid.

3. Jonathan Kozol, The Shame of the Nation (New York: Crown Publishers, 2005), 51.

4. Kozol, Shame of the Nation, 51.

5. Kozol, Shame of the Nation, 46.

6. Kozol, Shame of the Nation, 46.

7. Kozol, Shame of the Nation, 285.

8. Kozol, Shame of the Nation, 285.

9. Arlebe Inouye, "Standing Up to the Military Recruiters," Rethinking Schools Online 20, no. 3, (Spring 2005), http://rethinkingschools.org/archive/20_03/mili203.shtml.

10. David Goodman, "Class Dismissed," Mother Jones 29, no. 3 (2004), 43.

11. Nancy Hellmich, "McDonald's Kicks off School PE Program," USA Today, September 12, 2005. 